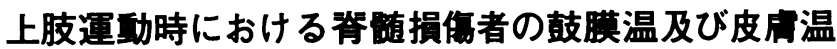

$\begin{array}{llll}\text { 石井好二郎* } & \text { 山崎昌廣* } & \text { 村木里志* } & \text { 小村 堯* } \\ \text { 菊地邦雄 } & \text { 宮側敏明** } & \text { 藤本繁夫** } & \text { 前田如 矢 }\end{array}$

\section{TYMPANIC TEMPERATURE AND SKIN TEMPERATURES DURING UPPER LIMB EXERCISE IN PATIENTS WITH SPINAL CORD INJURY}

\author{
Kojro Ishit, Masahiro Yamasaki, Satoshi Muraki, Takashi Komura, \\ Kunio Kikuchi, Toshiaki Miyagawa, Shigeo Fujmoto and Kazuya Maeda
}

\begin{abstract}
To clarify changes in body temperature during endurance exercise in patients with spinal cord injury ( $\mathrm{SCI}$ ), we measured tympanic temperature (Tty) and skin temperature in the head, arm, chest, thigh, shin and calf in 5 patients with SCI ( $\mathrm{T} 6-\mathrm{T} 12)$ and 7 normal controls during 30 minutes arm cranking exercise $(20$ watts) from 10 minutes before the initiation of exercise until 10 minutes after the termination of exercise in an artificial climate room at a temperature of about $25^{\circ} \mathrm{C}$ with a relative humidity of about $50 \%$. The Tty in the SCI group was lower than that in the control group from 10 minutes before the initiation of exercise to 10 minutes after the termination of exercise with a sig. nificant difference only at the initiation of exercise. The difference in Tty slightly decreased with continuation of exercise. The Tty in the SCI group at rest was $36.05 \sim 37.15{ }^{\circ} \mathrm{C}$. Four patients in this group showed a decrease of $0.04 \sim 0.12^{\circ} \mathrm{C}$ in the early stage and an increase of $0.66^{\circ} \mathrm{C} \pm 0.19$ (mean \pm $\mathrm{SD})$ at the end of exercise over the value at the initiation of exercise.

The skin temperature was lower in the SCI group than in the control group in all sites excluding the arm. Significant differences were observed in the head in the early stage of exercise and after exercise, in the chest from 10 minutes before the initiation of exercise to 5 minutes after the termination of exercise, in the thigh from 10 minutes before the initiation of exercise to 10 minutes after the termination of exercise, in the shin 10 minutes and 5 minutes before the initiation of exercise, and in the calf from before to 15 minutes after the initiation of exercise. In the SCI group, marked individual differences were observed in the skin temperatures in the thigh, shin, and calf, suggesting specificity of the skin temperature response in and near the paralysis area.

Results in Tty in this study suggested no heat retention in the SCI patients. Therefore, the risk for heat disorders seems to be low during moderate or mild exercise under moderate temperature environment at a temperature of about $25^{\circ} \mathrm{C}$ with a relative humidity of about $50 \%$ even when the skin temperature is low, and thermolysis is not marked.
\end{abstract}

(Jpn. J. Phys. Fitness Sports Med. 1995. $44: 447 \sim 456$ )

key words : spinal cord injury, exercise, thermoregulation

\section{I . 粕}

運動時に体温が上昇することはよく知られてい ることであり，その機序、及び生理学的意義につ いては数多くの研究がなされている. Nielsen ${ }^{1)}$
はこの運動による体温の上昇を熱産生と熱放散の 平衡が崩れたために起こるものではなく，筋運動 を円滑に遂行するために調節されたものであると している。.しかしながら，何らかの原因で自律神 経系に障害を生じている場合，熱産生と熱放散の
*広島大学総合科学部健康科学 干739 東広島市鏡山1-7-1

**大阪市立大学保健体育科研究室 于558 大阪市住吉区杉本3-3-138

***武庫川女子大学文学部教育学科 于 663 西宮市池開町6-46
Department of Health Science, Faculty of Integrated Arts and

Sciences, Hiroshima University, 1-7-1 Kagamiyama, Higashi Hiroshima-shi, Hiroshima 739, Japan

Department of Health Science and Physical Education, Osaka City

University, 3-3-138 Sugimoto, Sumiyoshi-ku, Osaka-shi, Osaka 558, Japan

Department of Education, School of Letters, Mukogawa Womens' University, 6-46 Ikebiraki-cho Nishinomiya-shi, Hyogo 663, Japan 
バランスを保つことが困難となる，脊膸損傷者 (SCI)は脊髄を損傷したことにより，しばしば自 律神経障害の発現が見られる。体温調節障害は SCI にとって起立性低血圧と並び発現頻度の高い自律 神経障害であり ${ }^{2)}$, リハビリテーションの進行や 日常の生活管理に支障を来すことも少なくない.

今や運動は SCI にとり, リハビリテーション の一環として, また, 残存機能のトレーニングと して，欠くことのできないプログラムの一つと なっている。しかし，SCI は体温調節障害のため 運動時に暑熱障害を起こしやすく，その対策につ いては検討する必要がある。現在, 我々はSCI の運動時における暑熱障害を予防する手段を考案 することを目的として研究を行っている，その研 究の一つとして, すでに我々は漸增運動負荷時に おける SCI の鼓膜温と皮虑温の動態について報 告した ${ }^{3) 4}$. しかしながら, 漸増運動負荷という 負荷形式の性質上， 3 - 15分で exhaustion に達 してしまったため, 持久的運動時における SCI の体温変動を知るには至らなかった。 そこで本研 究ではSCI に持久的運動を実施し, 体温変動の 観察を行ったところ, 健常者との差異, 及び SCI 間の個人差について幾つかの知見を得ることがで きたので報告する.

$$
\text { II. 方法 }
$$

\section{A. 対 象}

対象は本研究についてインフォームド・コンセ ントの得られた外傷性による SCI 5 名(T6-T 12) で(表1)ある.なお，この 5 名は月に $1 \sim 8$ 日, 車椅子バスケット,テニス等の運動を行っている. また, control 群として比較するため健康な男子

Table 1. Characteristics of SCI subjects.

\begin{tabular}{cccc}
\hline Subj. & $\begin{array}{c}\text { Age, } \\
\text { yr }\end{array}$ & $\begin{array}{c}\text { Time Since } \\
\text { Injury,yr }\end{array}$ & $\begin{array}{c}\text { Spinal Cord } \\
\text { Lesion Level }\end{array}$ \\
\hline 1 & 47 & 18 & T6 \\
2 & 35 & 15 & T6 \\
3 & 50 & 24 & T12 \\
4 & 50 & 20 & T12 \\
5 & 52 & 33 & T12* \\
\hline
\end{tabular}

${ }^{*}$ Incomplete lesion at $\mathrm{T} 12$.
大学生 7 名を選び, 対象と同様の実験, 及び測定 を行った。

\section{B. 実験手順}

$\mathrm{SCI}$ の運動時の体温に関しては, 環境温 $25^{\circ} \mathrm{C}$ 前

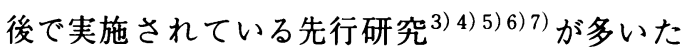
め, 本研究における実験も気温約 $25^{\circ} \mathrm{C}$, 相対湿度 約 $50 \%$ に調整された人工気候室内にて実施した。 対象は, 上半身裸体, 下半身は脚部が露出した状 態で人工気候室に入室し，60分間座位安静を保っ た後, Monark 社製 arm cranking ergometer Rehab Trainer $881 \mathrm{E}$ を用いて, arm cranking 運 動を30分間実施した。また，arm cranking の運 動負荷強度は, 対象全員が30分間実施可能な 20 watts $(50 \mathrm{rpm})$ とした。なお，すべての実験は体 温日周リズムの影響を軽隇するために 10 時より 16 時までの間に行った。

\section{C. 測定項目及び方法}

酸素攝取量は, 運動開始前 5 分間, 運動開始後 8〜10分, 18〜20分, 及び28〜 30分にダグラスバッ グ法により採集された呼気ガスを，乾式ガスメー ターで計量し, $\mathrm{O}_{2}$ 及び $\mathrm{CO}_{2}$ 濃度を Respina $\mathrm{IH}$ 26 (日本電気三栄社製)により分析， 1 分間当りに 換算したものを，それぞれを安静時, 運動開始 10 分後, 20 分後, 及び30分後とした. 心拍数はハー トレイトモニターPE-3000(ポーラエレクトロ社 製)を用いて 1 分毎に記録した. 深部体温として は鼓膜温を採用した，その理由としては，脊損者 の多くが排便障害を伴っており，排便管理が日常 生活を送る上で大きな問題となっているからで あった ${ }^{8)}$ ．そのような脊損者に対し直腸温を使用 するのは，精神的苦痛を増すことになると我々は 判断したのである.なお, 鼓膜温は Masuda and $\mathrm{Uchino}^{9)}$ が開発した運動時に測定可能なサーミス 夕鼓膜温測定装置を用い, 運動開始10分前から運 動終了10分後まで測定した. 皮屚温は, 運動開始 10分前から運動終了10分後まで額部, 上腕側部, 胸部, 大腿前部, 下腿前部, および下腿後部の計 6点を熱電対法により30秒毎に安立計器社製デー タコレクタ AM-2000を用いて記録した。

\section{D. 測定項目及び方法}

脊損者群と control 群の各測定項目について, 
それぞれ平均値と標準偏差を求めた. 平均値の差 の有意性は対応のない $\mathrm{t}$ 検定により, 酸素捸取量 は測定した全てを,それ以外は 5 分毎に検討した。 なお，統計処理の有意水準はいずれも危険率 $5 \%$ 末満とした。

\section{III. 結果}

\section{A. 健常者との差異}

図 1 に安静時および運動時の酸素攝取量を, 図 2 に運動開始10分前から運動終了10分後までの心 拍数を SCI 群と control 群とを比較して示した. 酸素搨取量, 及び心拍数共に SCI 群と control 群 間には統計的な有意差は認められず，また，その 推移もほほ同様のものであった。

図 3 に運動開始10分前から運動終了10分後まで の鼓膜温の推移を SCI 群と control 群とを比較し て示した.SCI 群は control 群に比べ低值を示す

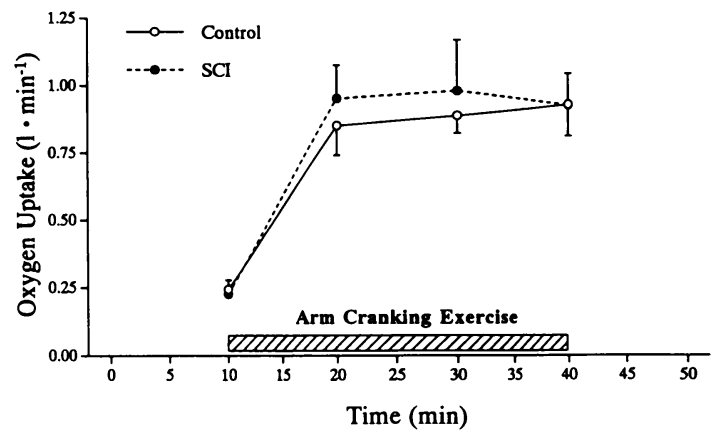

Fig. 1. Oxygen uptake changes before and during 30 min arm cranking exercise at 20 watts.

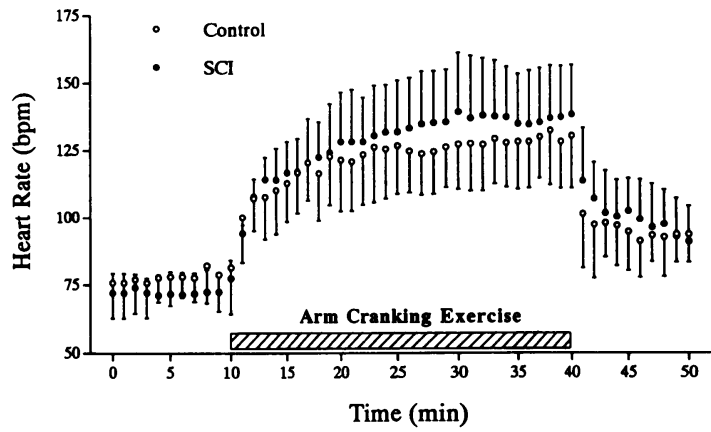

Fig. 2: Heart rate changes before, during, and after 30 min arm cranking exercise at 20 watts.

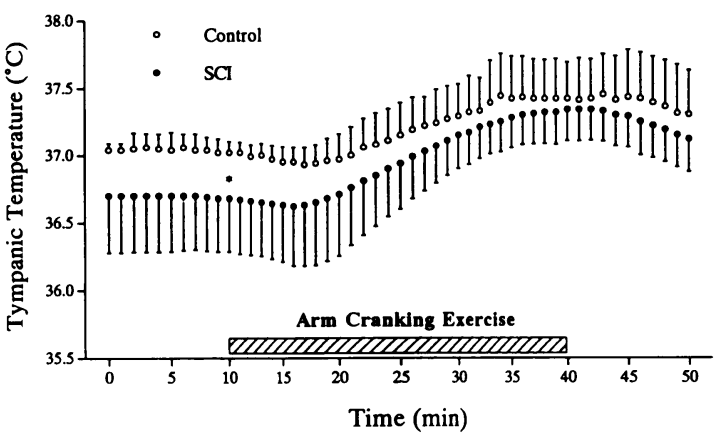

Fig. 3. Tympanic temperature changes before, during, and after $30 \mathrm{~min}$ arm cranking exercise at 20 watts.

Levels of significant difference found between $\mathrm{SCI}$ and control groups. ${ }^{*} \mathrm{p}<0.05$

傾向にあったが，統計的に有意差が認められたの は運動開始時のみであった。また，運動の持続と 共に両群間の差が縮まる傾向にあった。

図 4 に運動開始10分前から運動終了10分後まで の各部位の皮虑温の推移を SCI 群と control 群と を比較して示した。 上腕側部を除いて各部位の皮 庫温はSCI 群が低值を示す傾向が認められた。 統計的に有意差が認められたのは，額では運動初 期時, 及び運動終了後であり, 胸部では運動開始 10分後から運動終了 5 分後までであった。大腿前 部は全てにおいて有意に SCI 群が control 群に比 べ低值を示した。下腿前部では運動開始10分前, 及び5分前に, 下腿後部では運動開始前より運動 開始15分後までに統計的な有意差が認められた。

\section{B. SCI 間の体温変動の個人差について}

図 5 にSCI 各自の鼓膜温の推移を示した.SCI 群の安静時の鼓膜温は36.05 37. $15^{\circ} \mathrm{C}$ であり, 運 動開始後には 4 名に0.04 0.12 $\mathrm{C}$ の初期下降が認 められた。運動開始10分前後より鼓膜温の上昇傾 向は 1 名を除いて顕著となり, 運動終了時には運 動開始時より $0.66^{\circ} \mathrm{C} \pm 0.19($ mean $\pm \mathrm{SD})$ 上昇した。 安静時に最も低值を示していたSubj. 4 の上昇は $0.97^{\circ} \mathrm{C}$ と最も顕著なものであった，運動終了後に は全例において䋸やかな鼓膜温の下降が認められ た。

SCI 各自の皮成温の推移を図 6 に示した。額で は若干の推移の差は認められるものの個人間の皮 

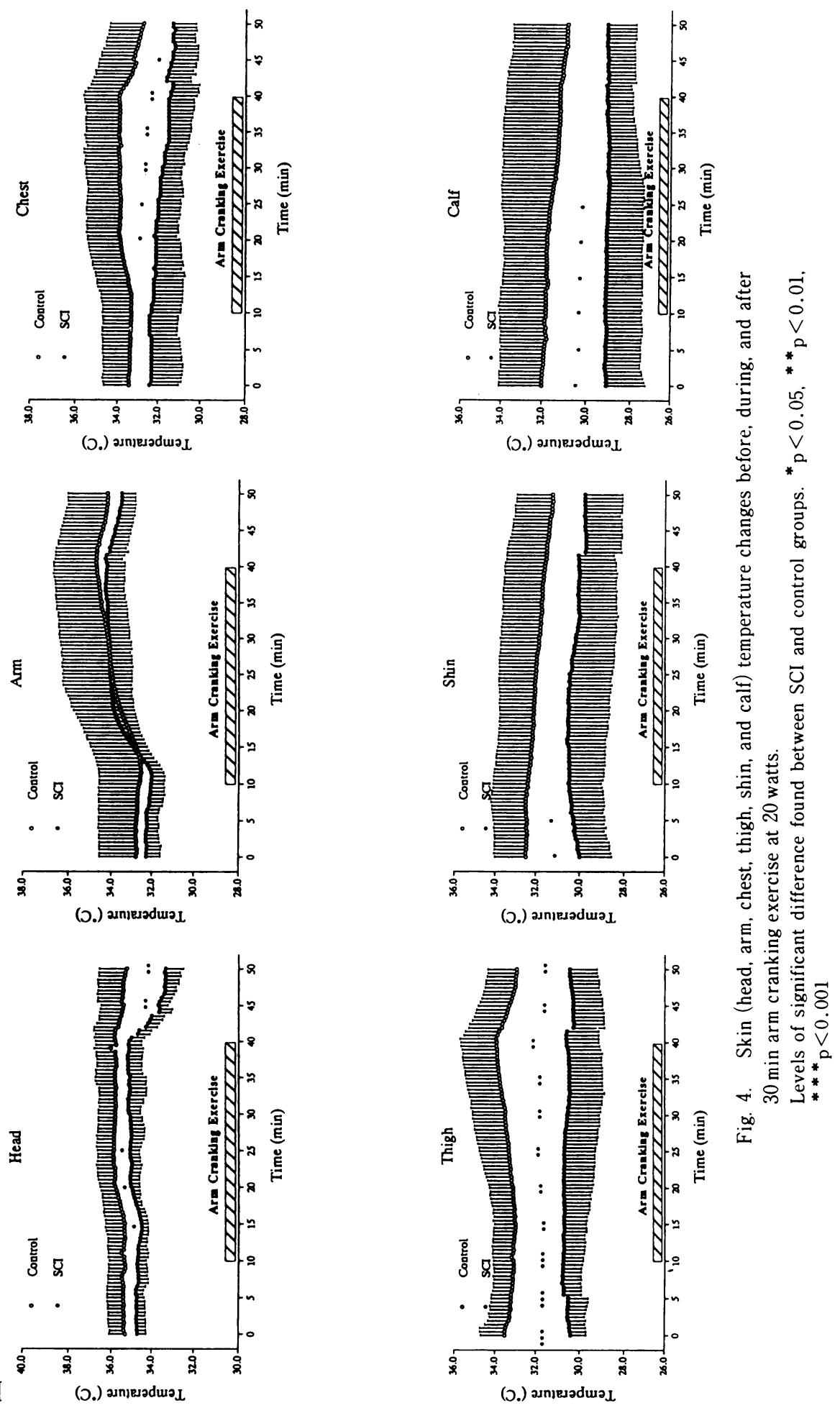


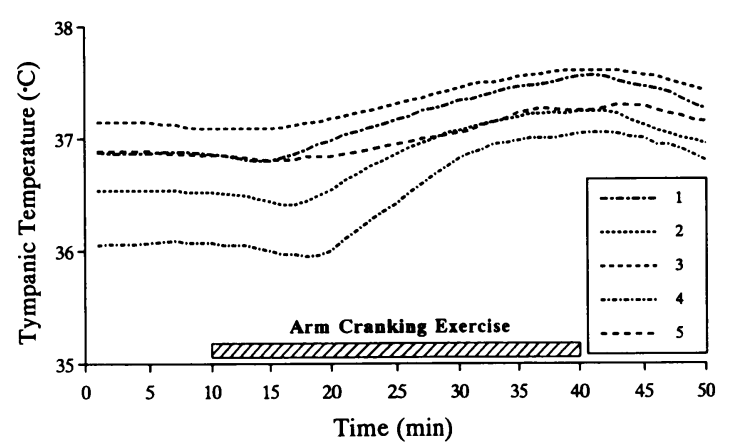

Fig. 5. Tympanic temperature changes before, during, and after $30 \mathrm{~min}$ arm cranking exercise for individual SCI subjects.

膚温差は小さいものであった。 上腕側部において は運動開始後に全対象において皮唐温の上昇を認 めるが，その推移には個人差が認められる．胸部 では安静時から個人間の皮虐温差が認められ，そ の推移も運動開始後に上昇を示す対象 1 名, 下降 の後, 上昇を示す対象 1 名, 下降を示す対象 3 名 と様々であった. 大腿前部, 下腿前部, 及び下腿 後部は本研究の対象の麻瘏域にあたる. 大腿前部 の皮膚温変動は様々であり, 運動中に上昇した対 象 1 名, 下降した対象 2 名, ほほ同じであった対 象 2 名となった。下腿前部の個人間の皮膚温差は 大きく, その推移も運動開始後約15分後より急激 な下降を示す対象や, 運動開始前から運動開始後 約10分まで上昇を示し，その後ほほ平坦となる対 象などが存在した。下腿後部においても個人間の 皮膚温差は大きかった。またその変動は, 運動中 上昇した対象 1 名, 下降した対象 1 名, ほほ同じ であった対象 2 名, 若干の下降の後, 上昇に転ず る対象 1 名となった。

\section{N. 考}

一般に体温上昇は酸素摂取量の相対値 $\left(\% \mathrm{~V}_{2} \max \right)$ で表わすと個人差がなくなることが 報告されており ${ }^{10)}$, 我々も当初は \% $\mathrm{VO}_{2} \max に$ 基づいた強度で運動負荷を実施することを考え た.しかしながら，1）健常者においても上肢運 動時の呼吸応答は回転運動の頻度の影響を受けや すく, 疲労にいたる時間が短縮されることが報告
されており ${ }^{11)} ， 2 ）$ 脊髄損傷によって麻痺した 呼吸筋や 12) 13)，3）高強度運動時での姿勢保持 が困難である等の影響から，回転数を一定にして 漸増負荷していく arm cranking ergometer を用 いての運動負荷テストでは, SCI の最大酸素搨取 量を知ることは困難であることを経験したため ${ }^{3)}$ 4), 20 watts の絶対值での一定負荷とした。 なお, 本研究の運動時に得られた SCI 群の酸素攝取量 を先行研究と比べて見ると, 本研究と同様に arm cranking ergometer を用いた Tam et al. ${ }^{14)}$ の報告 の $40 \% \mathrm{Wmax}$ (最大負荷の $40 \%$ 強度) 時とほほ同レ ベルであり,トレッドミル上に乗せた車椅子を用 いた Gass and Camp ${ }^{5)}$, 及び Gass et al. ${ }^{6)}$ の報告 $\left(60 \sim 65 \% \mathrm{~V}_{2} \max \right)$ に比べると少なく, 車椅子 ergometer を用いた Fitzgerald et al. ${ }^{7)}$ の報告 (50 〜 55\% peak $\mathrm{V}_{2}$ ) より若干多いものであった。こ のことから本研究の運動負荷はSCI にとり中等 度以下の強度であったと評価するのが妥当と思わ れる。

本研究のSCI 群の中には我々の先行研究 ${ }^{3)}$ 4) と同じく, 安静時に鼓膜温が非常に低值を示す 対象も存在したが, その理由としては麻瘏による 代謝量の低下が考えられる，未発表ではあるが 我々は麻瘏部位がさらに広範囲の頝䯣損傷者 (頝 損者)の 24 時間にわたる直腸温を測定し, 直腸温 が $35^{\circ} \mathrm{C}$ 代を示す䅡損者を数多く認めている. 麻痺 部位の範囲や残存機能の活動状況が代謝量を左右 し，体温の高低が生ずるものと思われる。

SCI 群の鼓膜温からは生理機能に影響を及ほす ようなうつ熱は認められない。しかしながら，運 動の持続と共に SCI 群と control 群の差が縮まる 傾向が認められている。この結果は熱放散の効率 の低下を示唆するものである，つまり，SCI は皮 膚温が低いため, 皮虐からの伝導, 対流, 及び放 射による熱放散が抑制され，その結果，貯熱量が 増加し, 鼓膜温の変化量が大きくなったものと思 われる．さらに長時間の運動を継続する場合には 貯熱量の増大が紫念され, 暑熱障害の危険性が高 まることが予想される。

運動時の鼓膜温初期下降は, 運動開始時の交感 神経興奮が全身皮虐血管を収縮させ, 環境温が皮 


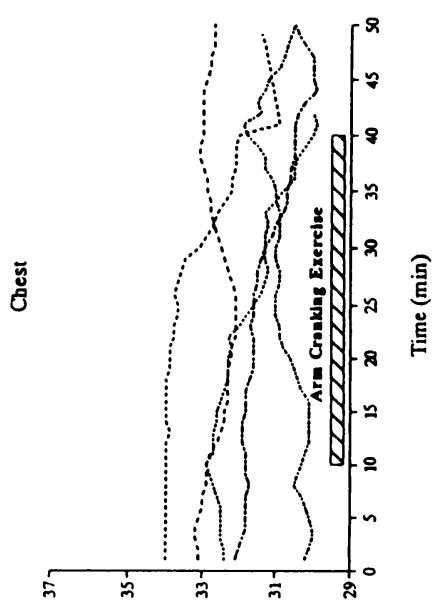

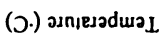
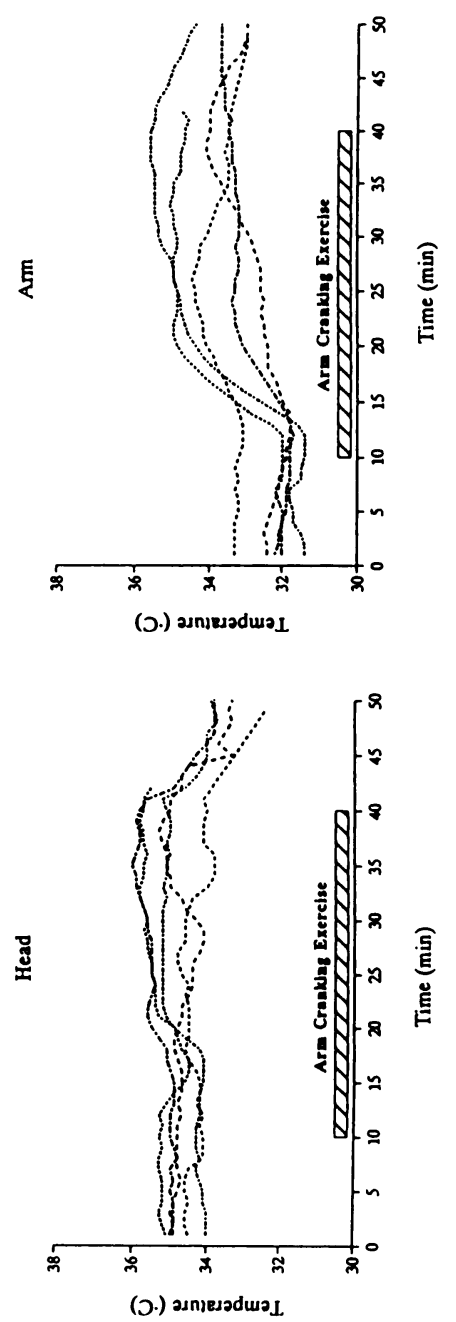

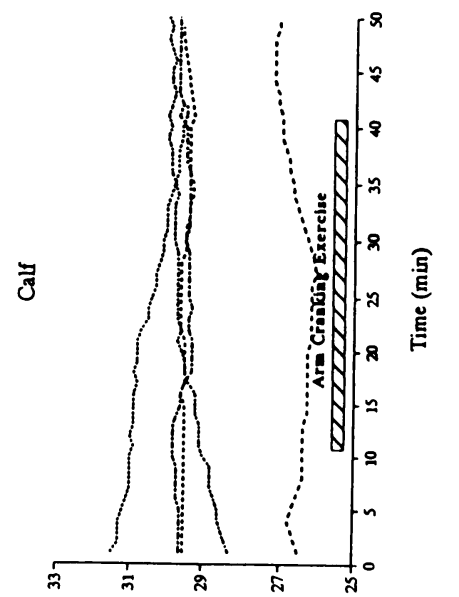

(ว.) มมก)ยวduroI

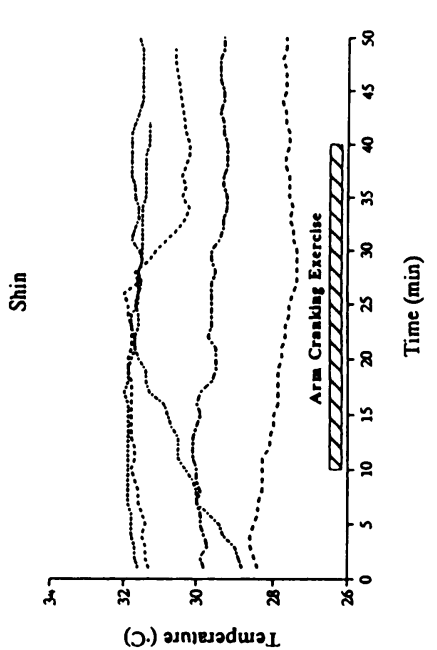

(ว.) อมกรยมอduั I

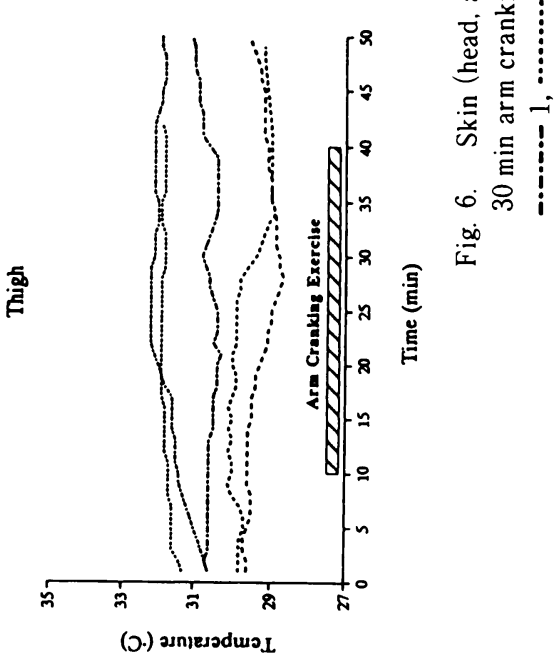


席温より低い場合, 低い皮虚静脈血が静脈還流し, その時の動静脈間の対向流熱交換によって冷やさ れた動脈血が原因とされている ${ }^{15)}$ 。増田 ${ }^{16)}$ は本 研究と同じ鼓膜温測定装置を用いて, 運動時の初 期下降は対象，及び運動強度の違いに関係なく発 現するとしている. しかし本研究の対象 5 名中 1 名に初期下降が認められなかったことや，初期下 降の幅がこれまで行われた健常者の報告 ${ }^{16) 17) に ~}$ 比へ個人差が大きかったことなどから，SCIにお いては皮庯感覚麻痺域での正常な皮㢆血管反応の 消失が鼓膜温初期下降の不出現や個人差の原因に なったものとも考えられる.

運動中の鼓膜温の推移は運動開始前に低值を示 した 2 名の上昇が比較的顕著であった. しかしそ の顕著な上昇は鼓膜温が $37^{\circ} \mathrm{C} に$ 近づきはじめた頃 より緩やかなものとなる。他の 3 名は安静時の鼓 膜温が $37^{\circ} \mathrm{C}$ 前後にあり, 運動開始後の上昇は緩や かであった. Benzinger ${ }^{18)}$ は皮膚温が $33^{\circ} \mathrm{C}$ 以上の 場合, 発汗はある一定の鼓膜温で始まり, 皮虐温 が低くくなれば発汗開始閾値の鼓膜温は高温側に 移動することを報告している。皮虙温 $33^{\circ} \mathrm{C}$ 以上の 発汗開始間值鼓膜温は $37^{\circ} \mathrm{C}$ 前後であり, 皮膚温 $30^{\circ} \mathrm{C}$ の場合で約 $37.4^{\circ} \mathrm{C}$ となっている ${ }^{18)}$. 本研究 の対象の運動時における鼓膜温の上昇が, $37^{\circ} \mathrm{C}$ 前 後で抑制されたのは発汗の影響も考えられ，運動 時における脳温維持のシステムが SCIにも存在 することを示㖫するものであろう。これらのこと より SCI の中温環境下での中等度以下の運動は, 30分程度では脳温維持の homeostasisにさほど影 響を及ほさないものと推察される。

本研究の対象の皮唐感覚麻瘏域には当たらない 胸部の皮膚温において，運動開始10分後から control 群との間に有意な差が認められたことは 非常に興味深い結果である。この原因としては, 皮虐感覚麻㽻域からの対流, 及び伝導の影響や, arm cranking 運動時に使用される筋群の参加の しかたの違いが考えられる。一般に arm cranking 運動時には, 胴体を固定するために他の筋組 織まで導入される ${ }^{19) 20)}$ 。しかし SCI の場合多く の筋群が麻㾝しているため, 胴体の固定が困難で あり, arm cranking 運動時に体幹のひねりを健
常者ほど加えることはできない.つまり健常者で は胸部でのダイナミックな動的筋収縮が可能であ り，そのことにより胸部の筋血流が増加し皮唐温 の上昇を招くのではないだろいか，これに対し SCI は残存する運動機能の差により胴体の固定に 使われる筋群も異なってくるため, 胸部の皮虑温 の変動に個人差が見られ, 健常者より低值であっ たものと思われる.

SCI 群の下肢の低い皮庙温は, 健常者に比べて 血流が少ないことを示唆している．特に大腿部に おいて顕著な差が認められたのは, 大腿部はマヒ による筋の萎縮が著しく現われる部位 ${ }^{4)}$ であるた めと考えられる．健常者の場合, 運動時には不活 動筋の筋血流は増加を示さず，むしろ血管収縮性 緊張のため筋血流はわずかに減少する ${ }^{21)}$. Hopman et al. ${ }^{22)}$ は SCIのarm cranking 運動時, 及び 回復時の腓腹部 (calf)の容積を測定し, 健常者と 比較してその変化が軽度であったことを認め, こ の成績より障害部の交感神経興奮による血管収縮 性緊張は停止または低下し, 上肢運動時に下肢で の効果的な血液の配分が不可能となっていると報 告している. 本研究において運動開始後に SCI 群と control 群の下肢の皮膚温差が縮まる傾向に あったのは, control 群では血液の再分配により 下肢への血流が滅少し, その結果, 元々, 下肢血 流の少ないSCI 群との皮庙温差が縮まったもの と思われる。

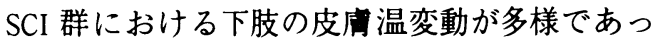
たことから，上肢運動に対する下肢の血流変化に は個人差があると推測される．SCI は脊髄を損傷 したことにより自律神経系の伝達経路に変化が生 じている，また，障害の程度も様々であり，これ ら種々の要因により個人差が出現しやすくなるも

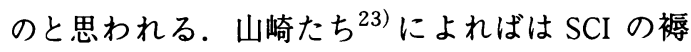
瘡予防に対するスポーツ活動の効果は明らかにで きなかったと報告している，上肢運動時における 下肢血流の個人差がスポーツ活動の褯瘡予防への 有効性を左右するのかもしれない. 皮虐血流の増 大は静脈環流を減少させる，脊損者の下肢の低い 皮虏温は, 筋ポンプ能力の低下により静脈環流能 力が低下している SCIにとり22) 24)25)26)27)28)，中 
枢部の循環を維持するための代償性作用になって いるとも考えられる.

\section{V. 要 粎}

脊髄損傷者 $(\mathrm{SCI})$ の持久的運動時における体温 変動を知ることを目的とし, SCI 5 名（T 6-T 12）, 及び control 7 名(健常者)に気温約 $25^{\circ} \mathrm{C}$, 相対湿 度約 $50 \%$ に調整された人工気候室内において， arm cranking 運動 (20 watts) を30分間実施させ, 運動開始10分前から運動終了10分後までの鼓膜温 (Tty) 及び皮席温(額部, 上腕側部, 胸部, 大腿 前部, 下腿前部, 及び下腿後部)を測定し, 以下 の結果を得た. SCI 群の Tty は control 群に比べ, 運動開始10分前から運動終了10分後まで低值を示 す傾向にあったが, 統計的に有意差が認められた のは運動開始時のみであった．また，運動の持続 と共に両群間の Tty の差が縮まる傾向にあった。 なお, SCI 群の安静時の Tty は36.05 37.15 ${ }^{\circ} \mathrm{C}$ であり, 運動開始後には SCI 群の内 4 名に 0.04 $\sim 0.12^{\circ} \mathrm{C}$ の初期下降が認められ, 運動終了時には 運動開始時より $0.66^{\circ} \mathrm{C} \pm 0.19($ mean $\pm \mathrm{SD})$ 上昇し た。

上腕側部を除いて各部位の皮夙温は SCI 群が 低值を示す傾向が認められた。統計的に有意差が 認められたのは, 額部では運動初期時, 及び運動 終了後であり, 胸部では運動開始10分後から運動 終了 5 分後までであった。 大腿前部は運動開始 10 分前から運動終了10分後までの全てにおいて有意 にSCI 群が control 群に比べ低值を示した。下腿 前部では運動開始10分前, 及び 5 分前に, 下腿後 部では運動開始前より運動開始15分後までに統計 的な有意差が認められた. SCI の胸部, 大腿前部, 下腿前部，および下腿後部の皮虑温は個人差が顕 著であり，SCI の麻瘏域や麻瘏域に近い部位にお ける皮局温反応の特異性が示唆された。

\section{(受付 平成 7 年 2 月 2 日)}

\section{参考献}

1) Nielsen, M. Die Regulation der Kopertemperatur bei Muskelarbeit. Skand. Arch. Physiol., (1938), 79, 193-230.
2）緒方 甫. 自律神経障害の発症機序 (起立性低血 圧・体温調節障害)。リハビリテーション基礎医学, 初版, 上田 敏, 千野直一, 岩倉博光編, 医学書院, 東京, (1983), 244-259.

3）石井好二郎, 山畸昌廣, 村木里志, 小村 堯, 菊 地邦雄, 坂手照憲, 前田如矢. 漸增抵抗運動時に おける脊㵦損傷者の鼓膜温及び皮㚜温。日本運動 生理学雑誌, (1994), 1 (2), 27-32.

4) Ishii, K., Yamasaki, M., Muraki, S., Komura, T., Kikuchi, K. \& Maeda, K. Exercise-inducedtemperature changes in the tympanic membrane and skin of patients with spinal cord injury. In : Yabe, K., Kusano, K. and Nakata, H. (Eds.) Adapted physical Activity. Springer-Verlag, Tokyo, (1994), 77-83.

5) Gass, G. C. \& Camp, E. M. Prolonged exercise response in trained male paraplegics. Thermal Phy. siology. Hales, J. R. S. (Ed.), Raven Press, New York, (1984), 429-432.

6) Gass, G. C., Camp, E. M., Nadel, E. R., Gwinn, T. H. \& Engel, P. Rectal and rectal vs. esophageal temperatures in paraplegic men during prolonged exercise. J. Appl. Physiol., (1988), 64, 2265-2271.

7) Fitzgerald, P. I., Sedlock, D. A. \& Knowton, R. G. Circulatory and thermal adjustments toprolonged exercise in paraplegic women. Med. Sci. Sports Exerc., (1990), 22, 629-635.

8）高坂 哲, 石堂哲郎, 宮崎一興, 脊跹損傷者の排 便管理. 排尿排便障害 - 性機能障害, 初版, 岩倉 博光, 岩谷 力, 土肥信之編, 医歯薬出版, 東京, (1990), 85-100.

9) Masuda, M. \& Uchino K. A device for tympanic membrane temperature in man. Jikeikai Med. J., (1978), 25, 95-99.

10) Saltin, B. \& Hermansen, L. Esophageal, rectal and muscle temperature during exercise. J. Appl. Physiol., (1966), 21, 1757-1762.

11) Vokac, Z., Bell, H., Bautz-Holter, E. \& Rodahl, K. Oxygen uptake/heart rate relationship inleg and arm exercise, sitting and standing. J. Appl. Physiol., (1975), 39, 54-59.

12）富永皘生. 救急処置. 脊㖪損傷の実際一病態から 管理まで一, 初版, 赤津 隆, 新宮彦助, 井形高 明編, 南江堂, 東京, (1991), 66-81.

13) Yamasaki, M., Irizawa, M., Ishii, K. \& Komura, T. Work efficiency ofparaplegics during armcranking exercise. Ann. Physiol. Anthrop., (1993), 12, 79-82.

14) Tam, H. S., Darling, R. C., Cheh, H. Y. \& Downey, J. 
A. Sweating respose: a means ofevaluating the set-point theory during exercise. J. Appl. Physiol., (1978), 45, 451-458.

15) Caputa, M. \& Cabanac, M. Muscular works as thermal behavior in humans. J. Appl. Physiol., (1980), 48, 1020-1023.

16）増田 允. 運動と体温. 東京慈恵会医科大学雑誌, (1975)，90，1-15.

17）内野欽司. 口腔温, 鼓膜温, 腋㸗温, 直腸温なと の意義と相関. 臨床体温, (1989)，9(2)，48-59.

18) Benzinger, T. H. Heat regulation: Homeostasis of central temperature in man. Physiol.Rev., (1969), 49, 671-759.

19) Clausen, J. \& J. Trap-Jensen. Heart rate and arterial blood pressure during exercise inpatients with angina pectoris. Circulation, (1976), 53, 436-442.

20) Schwade, J., Blomqvist, C. G. \& Shapiro, W. A comparison of the response to arm and legwork patients with ischemic heart disease. Am. Heart J., (1977), 94, 203-208.

21) Johnson, J. M. \& Rowell, L. B. Forearm skin and muscle vascular responses to prolonged legexercise in man. J. Appl. Physiol., (1975), 39, 920-924.

22) Hopman, M. T. E., Pistorius, M., Kamerbeek, I. C. E. \& Binkhorst, R. A. Cardiac output inparaplegic sub. jects at high exercise intensities. Eur. J. Appl. Phy- siol., (1993), 66, 531-535.

23）山崎昌廣, 小村 堯, 藤家 馨, 佐々木久登, 甲 斐健览, 春髄損傷者の車椅子スポーツ活動には裖 㾑形成に対する予防効果があるか? . 体力科学, (1994)，43，121-126.

24) Bevegard, S., Freyschuss, U. \& Standell, T. Circulatory adaptation to arm and leg exercise insupine and sitting position. J. Appl. Physiol., (1966), 21, 37-46.

25) Pollock, M. L., Miller, H. S., Linnaud, A. C., Laughridge, E., Coleman, E. \& Alexander, E. Arm pedalling as an endurance training regimen for the disabled. Arch. Phys. Med. Rehabil., (1974), 55, 418-424.

26) Bar-Or, O., Inbar, O. \& R. Spira Physiological effects of a sports rehabilitation program oncerebral palsied and post poliomyelitic adolescents. Med. Sci. Sports, (1978), 8, 157-161.

27) Hopman, M. T. E., Oeseburg, B. \& Binkhorst, R. A. Cardiovascular responses in paraplegicsubjects during arm exercise. Eur. J. Appl. Physiol., (1992), 65, 73-78.

28) Hopman, M. T. E., Verheijen, P. H. E. and Binkhorst, R. A. Volume changes in the legs of paraplegic subjects during arm exercise. J. Appl.Physiol., (1993), 75, 2079-2083. 